\title{
Probiotic white cheese production using coculture with Lactobacillus species isolated from traditional cheeses
}

\author{
A. Ehsani ${ }^{1}$, M. Hashemi ${ }^{2}$ A. Afshari ${ }^{2}$ and M. Aminzare ${ }^{3}$
}

1. Department of Food Science and Technology, Faculty of Nutrition, Tabriz University of Medical Sciences, Tabriz, Iran; 2. Department of Nutrition, Faculty of Medicine, Mashhad University of Medical Sciences, Mashhad, Iran; 3. Department of Food Safety and Hygiene, School of Public Health, Zanjan University of Medical Sciences, Zanjan, Iran. Corresponding author: Asma Afshari, e-mail: asmafshr@gmail.com

Co-authors: AE: ehsani@tbzmed.ac.ir, MH: mo_hashemi@hotmail.com, MA: m.aminzare@zums.ac.ir Received: 26-02-2018, Accepted: 27-04-2018, Published online: 30-05-2018

doi: 10.14202/vetworld.2018.726-730 How to cite this article: Ehsani A, Hashemi M, Afshari A, Aminzare M (2018) Probiotic white cheese production using coculture with Lactobacillus species isolated from traditional cheeses, Veterinary World, 11(5): 726-730.

\begin{abstract}
Aim: The aim of the present study was to investigate the viability of lactic acid bacteria isolated from traditional cheeses and cocultured in Iranian white cheese during ripening.

Materials and Methods: A total of 24 samples were isolated from 8 types of traditional cheeses in West Azerbaijan, Iran. Isolated species were cocultured with starter bacteria during the production of Iranian white cheese, and their viability was investigated up to 60 days of the refrigerated storage.

Results: Of 118 isolates of Lactobacillus, 73 isolates (62\%) were confirmed as facultative heterofermentative and 45 isolates (38\%) as obligate homofermentative. Of the facultative heterofermentatives, 28 isolates (24\%) were Lactobacillus plantarum, 24 isolates (20\%) were Lactobacillus casei, and 21 isolates (18\%) were Lactobacillus agilis. Obligate homofermentatives were Lactobacillus delbrueckii (21\%), Lactobacillus helveticus (14\%), and Lactobacillus salivarius (3\%). L. plantarum, L. casei and L. helveticus were found in high enough levels $\left(10^{6} \mathrm{CFU} / \mathrm{g}\right)$.
\end{abstract}

Conclusion: According to the obtained data, it is recommended that complex starters such as L. helveticus, L. plantarum, and $L$. casei can be used in industrial productions of cheese to obtain exclusive properties of traditional cheeses.

Keywords: heterofermentative, Lactobacillus, probiotic, starter, traditional cheeses.

\section{Introduction}

Cheeses made from pasteurized milk have better hygienic quality and uniform texture than traditional ones; however, pasteurization has some devastating effects on the quality of the cheese as it can destroy the flavor-producing microorganisms. To overcome this problem, traditional starters are added after pasteurization [1]. Therefore, knowing the composition of lactic flora, naturally present in traditional cheeses, provides safe and standard starters while maintaining the essential characteristics [2].

Since West Azerbaijan Province (Iran) has environmental and ethnic diversity, there are varieties of traditional foods, particularly dairy products, in this region [3]. There are different kinds of cheese traditionally produced in this region. Urmia Koopeh Cheese is a fermented milk product and one of the most traditional and popular cheese in the West and North-West of Iran, Turkey, and Northern areas of Iraq. It is a semisoft sheep cheese

Copyright: Ehsani, et al. Open Access. This article is distributed under the terms of the Creative Commons Attribution 4.0 International License (http://creativecommons.org/licenses/by/4.0/), which permits unrestricted use, distribution, and reproduction in any medium, provided you give appropriate credit to the original author(s) and the source, provide a link to the Creative Commons license, and indicate if changes were made. The Creative Commons Public Domain Dedication waiver (http://creativecommons.org/ publicdomain/zero/1.0/) applies to the data made available in this article, unless otherwise stated. and is produced without using any starter. Another popular cheese in this area is Lighvan, which is a soft cheese (60\% humidity) traditionally produced from raw sheep and goat milk without adding any starter culture [4], the fermentation also depends on the lactic flora of the raw milk. Lighvan cheese is one of the most common dairy products in Iran [5]. Shal cheese, which is also called fresh cheese, is produced traditionally in Urmia in West Azerbaijan province in large casts and has popularity in this region. Salty cheese is another milk product, traditionally made from boiled buttermilk along with salt. In this process, the clot-on-boiling is filtered, and consequently, the result is a salty cheese with particular aroma and flavor [5].

The traditional production of cheese and the replacement of traditional lactic acid bacteria with a variety of non-native microflora are a future possibility in dairy technology; therefore, it would be encouraging for researchers to collect different strains and species of lactic acid bacteria from different dairy products obtained from various regions.

The aim of the current study was to isolate Lactobacillus species from different traditional cheeses of West Azerbaijan province, Iran, to produce a white cheese with a uniform texture and a flavor similar to that of traditional cheeses as well as determining starter's viability in dairy products. 


\section{Materials and Methods}

\section{Ethical approval}

This study was approved by the Research Committee of Urmia University, Urmia, Iran.

\section{Sampling}

A total of 24 samples (250 g) were collected from 8 traditional cheeses of different geographical regions in West Azerbaijan (Urmia, Bukan, Mahabad, Sardasht, and Maku), Iran, as follow: Triplicate samples from five different types of Koopeh cheese (15 samples), Shal fresh cheese (3 samples), Lighvan cheese (3 samples), and Salty cheese (3 samples). Samples were kept at $4^{\circ} \mathrm{C}$ for further analysis.

\section{Isolation of lactic acid bacteria}

Amount of $25 \mathrm{~g}$ of each sample was aseptically weighted and homogenized with $225 \mathrm{ml}$ of sodium citrate using a stomacher (Seward Stomacher 400 Circulator, UK). Samples were subsequently diluted $(1: 10)$ using sterile peptone water and $0.1 \mathrm{ml}$ from each dilution was sub-cultured on Man Rogosa and Sharpe (MRS) agar (Merck, Germany) used for isolating lactic acid bacteria [6]. Plates were incubated at $30^{\circ} \mathrm{C}$ and $37^{\circ} \mathrm{C}$ for mesophilic lactic acid bacteria and at $42^{\circ} \mathrm{C}$ for thermophilic lactic acid bacteria for 48 h. MRS agar plates were incubated anaerobically using the gas pack systems (Anaerocult C, Merck, Germany). To differentiate homo- and heterofermentative strains, all the isolates were tested for gram reaction, catalase production, and carbohydrates fermentation (homofermentatives showed ribose + , sorbitol + , raffinose \pm , lactose + , galactose + , maltose + , melibiose \pm , rhamnose - , xylose \pm , manose + , salicine + , sorbose + , glucose + , and sucrose + pattern, heterofermentatives showed ribose + , sorbitol \pm , raffinose \pm , lactose \pm , galactose \pm , maltose + , melibiose \pm , rhamnose \pm , xylose - , manose + , salicine \pm , sorbose \pm , glucose + , and sucrose \pm pattern). Cimon citrate test was also conducted as a differential test $[7,8]$.

\section{Iranian white cheese preparation}

Starter (Chr. Hansen R 704: Lactococcus lactis Subsp., cremoris and L. lactis Subsp., diacetyl lactis) and isolated Lactobacillus species were added $\left(0.5 \% \mathrm{w} / \mathrm{v}\right.$ and $10^{9} \mathrm{CFU} / \mathrm{ml}$, respectively) to each vat of pasteurized cow milk $\left(65^{\circ} \mathrm{C}\right.$ for $\left.30 \mathrm{~min}\right)$ separately. A solution of 20 g. 100/ $\mathrm{L} \mathrm{CaCl}_{2}$ was added to each batch, and the fermentation continued for 2-4 $\mathrm{h}$ until the $\mathrm{pH}$ reached to $6.1-6.2$. Then, $0.001 \% \mathrm{w} / \mathrm{v}$ of rennet was added to each vat to coagulate the milk. To improve the efficiency of rennet, the milk temperature was maintained at about $35^{\circ} \mathrm{C}$ during the formation of cheese clots. After coagulation, the curds were divided into small cubes (1-2 $\left.\mathrm{cm}^{3}\right)$ and pressed. Cheese samples were allowed to rest in $20 \% \mathrm{w} / \mathrm{v}$ brine salt for $8 \mathrm{~h}$ and in $8 \%$ sterile brine-salt for 15 days at $12-14^{\circ} \mathrm{C}$. Final ripening applied for 45 days at $4^{\circ} \mathrm{C}$ [9]. The manufacture of Iranian white cheese was performed in triplicate for each treatment. Lactobacillus count was performed $1 \mathrm{~h}$ after inoculation and on days 3, 7, 15, 30, 45, and 60 .

\section{Lactobacillus viable cell counts}

For viability assessment of probiotic bacteria during 60 days of storage at refrigerator temperature, $10 \mathrm{~g}$ of cheeses were homogenized with $90 \mathrm{~mL}$ of sterile sodium citrate using a stomacher. Decimal dilutions in peptone water were prepared and plated on MRS agar (Merck, Germany). Plates were incubated at $37^{\circ} \mathrm{C}$ for $48 \mathrm{~h}$ [9]. Finally, colonies were Gram stained, and catalase production, carbohydrates fermentation, and Cimon citrate test were performed.

\section{Results}

A total of 118 Lactobacillus isolates were identified from 4 different kinds of cheese. Phenotypic characterization of isolates, such as gram reaction, catalase production, and carbohydrates fermentation (Table-1), resulted in the identification of 73 isolates (62\%) of Lactobacillus as facultative heterofermentative and 45 isolates (38\%) as obligate homofermentative.

Facultative heterofermentatives were composed of 28 isolates (24\%) of Lactobacillus plantarum, 24 isolates (20\%) of Lactobacillus Casei, and 21 isolates (18\%) of Lactobacillus agilis. Obligate homofermentative Lactobacillus species were composed of 25 isolates (21\%) of Lactobacillus delbrueckii, 16 isolates (14\%) of Lactobacillus helveticus, and 4 isolates (3\%) of Lactobacillus salivarius. 58 Lactobacillus isolates (49\%) were identified at $30^{\circ} \mathrm{C}, 15$ isolates $(13 \%)$ at $37^{\circ} \mathrm{C}$, and 45 isolates $(38 \%)$ at $42^{\circ} \mathrm{C}$. Distribution of Lactobacillus isolates in traditional cheeses is shown in Figure-1.

Lactobacillus viability of probiotic white cheese samples during 60 days of storage is presented in Table-2. The viability of L. helveticus, L. plantarum,

Table-1: Results of Gram staining and biochemical tests of Lactobacillus species.

\begin{tabular}{|c|c|c|c|c|c|c|}
\hline \multirow[t]{2}{*}{ Tests } & \multicolumn{6}{|c|}{ Bacterial strain } \\
\hline & 1 & 2 & 3 & 4 & 5 & 6 \\
\hline Gram staining & + & + & + & + & + & + \\
\hline Ribose & + & + & + & + & + & + \\
\hline Sorbitol & + & + & + & - & + & + \\
\hline Raffinose & + & - & + & - & - & + \\
\hline Lactose & + & + & + & - & + & + \\
\hline Galactose & + & + & + & + & - & + \\
\hline Maltose & + & + & + & + & + & + \\
\hline Melibiose & + & - & - & + & - & + \\
\hline Rhamnose & - & - & - & + & - & - \\
\hline Xylose & - & - & + & - & - & - \\
\hline Manose & + & + & + & + & + & + \\
\hline Salicine & + & + & + & - & + & + \\
\hline Sorbose & + & + & + & + & - & + \\
\hline Glucose & + & + & + & + & + & + \\
\hline Sucrose & + & + & + & - & + & + \\
\hline $\mathrm{CO}_{2}$ production from glucose & + & - & + & - & - & + \\
\hline Growth at $30^{\circ}$ & + & + & + & - & - & + \\
\hline Growth at $37^{\circ}$ & + & + & - & + & - & + \\
\hline Growth at $42^{\circ}$ & - & - & - & + & + & - \\
\hline Catalase & - & - & - & - & - & - \\
\hline Citrate & + & - & - & + & - & + \\
\hline
\end{tabular}

1 =Lactobacillus plantarum, 2=Lactobacillus casei, 3=Lactobacillus agilis, 4=Lactobacillus helveticus, 5=Lactobacillus delbrueckii, 6=Lactobacillus salivarius 


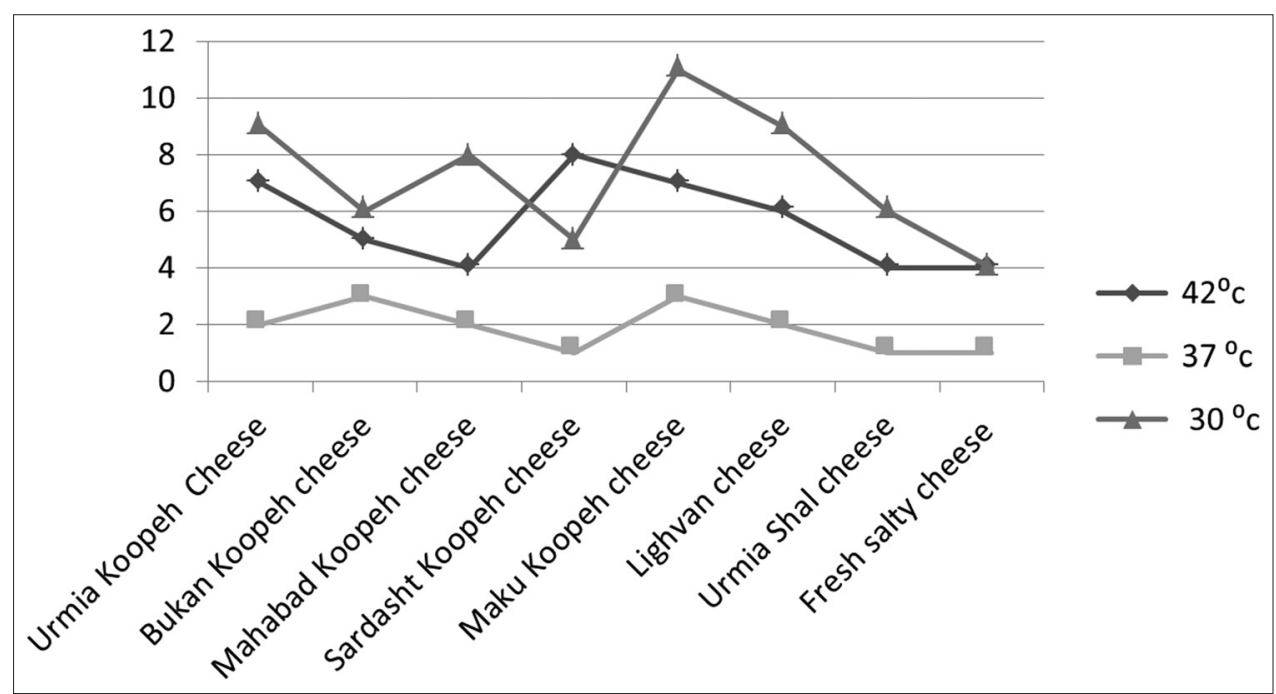

Figure-1: Lactobacillus isolates in various traditional cheeses at different temperatures.

Table-2: Lactobacillus viability of probiotic white cheese samples during storage time (mean values \pm SD).

\begin{tabular}{|c|c|c|c|c|c|c|c|}
\hline \multirow[t]{3}{*}{ Lactobacillus species } & \multicolumn{7}{|c|}{ Lactobacillus count $\left(\log _{10} \mathrm{CFU} / \mathrm{g}\right)$} \\
\hline & \multicolumn{7}{|l|}{ Time (days) } \\
\hline & $\mathbf{0}$ & 3 & 7 & 15 & 30 & 45 & 60 \\
\hline L. plantarum & $9.81 \pm 0.03^{\mathrm{Aa}}$ & $8.96 \pm 0.01^{\mathrm{Ab}}$ & $7.95 \pm 0.00^{A C}$ & $7.74 \pm 0.04^{\mathrm{Ad}}$ & $6.72 \pm 0.04^{\mathrm{Ae}}$ & $6.63 \pm 0.06^{\text {Aef }}$ & $6.52 \pm 0.07^{\mathrm{Af}}$ \\
\hline L. casei & $9.73 \pm 0.1^{\mathrm{Aa}}$ & $8.92 \pm 0.01^{\mathrm{ABb}}$ & $7.79 \pm 0.04^{\mathrm{Bc}}$ & $6.94 \pm 0.02^{\mathrm{Bd}}$ & $6.61 \pm 0.12^{\mathrm{Ae}}$ & $6.36 \pm 0.1^{\mathrm{Bf}}$ & $6.50 \pm 0.04^{\text {Aef }}$ \\
\hline L. agilis & $9.82 \pm 0.05^{\mathrm{Aa}}$ & $8.84 \pm 0.00^{\mathrm{BCb}}$ & $7.60 \pm 0.00^{\mathrm{BC}}$ & $6.52 \pm 0.07^{c d}$ & $5.91 \pm 0.01^{\mathrm{Be}}$ & $5.72 \pm 0.04^{\mathrm{cf}}$ & $5.52 \pm 0.07^{\mathrm{Bg}}$ \\
\hline L. helveticus & $9.32 \pm 0.12^{\mathrm{Ba}}$ & $8.81 \pm 0.03^{\mathrm{cb}}$ & $8.07 \pm 0.22^{A C}$ & $7.78 \pm 0.01^{\mathrm{Ac}}$ & $6.61 \pm 0.02^{\text {Ade }}$ & $6.36 \pm \pm 0.10^{\mathrm{Be}}$ & $6.72 \pm 0.04^{\mathrm{Ad}}$ \\
\hline L. delbrueckii & $9.44 \pm 0.12^{\mathrm{Ba}}$ & $8.52 \pm 0.07^{\mathrm{Db}}$ & $7.87 \pm 0.05^{A B C}$ & $6.82 \pm 0.04^{\mathrm{Bd}}$ & $4.36 \pm 0.10^{\mathrm{Ce}}$ & $4.67 \pm 0.05^{\mathrm{Df}}$ & $4.56 \pm 0.07^{\mathrm{Ce}}$ \\
\hline L. salivarius & $9.77 \pm 0.07^{\mathrm{Aa}}$ & $9.48 \pm 0.03^{\mathrm{Eb}}$ & $7.62 \pm 0.03^{B C}$ & $5.79 \pm 0.08^{\mathrm{Dd}}$ & $4.98 \pm 0.03^{\mathrm{De}}$ & $4.94 \pm 0.03^{\mathrm{Ee}}$ & $4.72 \pm 0.04^{\mathrm{Ce}}$ \\
\hline
\end{tabular}

Same small letters within the same row indicate non-significant differences ( $p>0.05$ ) based on Tukey's Range Test. Same capital letters within the same column indicate non-significant differences ( $p>0.05)$ based on Tukey's range test, $\mathrm{SD}=$ Standard deviation, L. plantarum=Lactobacillus plantarum, L. casei=Lactobacillus casei, L. agilis=Lactobacillus agilis, L. helveticus=Lactobacillus helveticus, L. delbrueckii=Lactobacillus delbrueckii, L. salivarius=Lactobacillus salivarius

and L. casei was observed above $6 \mathrm{Log} \mathrm{CFU} / \mathrm{g}$, throughout 60 days of storage period. L. plantarum and $L$. casei were different from L. helveticus, and the differences were statistically significant $(\mathrm{p}<0.05)$. Other species declined below $6 \mathrm{log} \mathrm{CFU} / \mathrm{g}$ after 30 days of storage (Table-2).

\section{Discussion}

Knowing the microbial population of traditional dairy products results in better understanding of specific characteristics of such products [10]. The technology used in the different geographical area in producing traditional dairy products has a direct impact on the diversity of the microbial population [10,11]. Lactobacillus species are identified as dominant species in cheeses produced from raw milk because they can grow under severe selective conditions and cause desirable sensory properties due to their proteolytic activities [12]. In the current study, mesophilic strains of Lactobacillus were dominant lactic flora of traditional cheeses since $62 \%$ of Lactobacillus strains were isolated at $30^{\circ} \mathrm{C}$ and $37^{\circ} \mathrm{C}$. In a study by Ahmadi et al. [13], on lactic acid bacteria of Lighvan cheese, mesophilic (85\%, 46 isolates) and thermophilic (15\%, 8 isolates) Lactobacillus were isolated, respectively. Previous studies indicated that facultative heterofermentative Lactobacillus, especially L. plantarum and L. casei, is the most typical isolated lactobacilli from cows and sheep milk [14], which can also produce specific flavor and aroma [15]. In a previous study on Fossa cheese, it was determined that L. plantarum, $L$. paracasei, and L. carvatus produce small peptides and volatile amino acids during activities of dipeptidase, aminopeptidase, endopeptidase, and proteinase enzymes, leading to the production of desirable flavor and aroma [16]. In other studies, these bacteria were identified as dominant species of Iranian Lighvan cheese, South African traditional fermented milk and Maasai traditional fermented milk (Kenya) which are all consistent with the results of this study [17-19]. These results confirm the important role of lactic acid bacteria isolated from traditional cheeses.

In this study, L. plantarum was the dominant Lactobacilli of traditional cheeses, especially Urmia Koopeh cheese. Of 118 isolated Lactobacillus strains, 28 isolates $(24 \%)$ were L. plantarum. These mesophilic bacteria are able to fermentate citrate and proteolysis during cheese curing [20]. Results of similar studies have shown such differences in the microbial 
composition of fermented foods, using culture-dependent and independent methods [21].

Lactic acid bacteria are responsible for potential usefulness of fermented milk products [22]. Many researchers have studied the antibacterial activity of lactic acid bacteria and their ability to produce antimicrobial substances and destroying pathogens $[23,24]$.

In recent years, various preservatives including natural additives have been introduced to overcome pathogenic microorganisms $[25,26]$. The effect of lactic acid bacteria in preventing the growth of pathogens plays a vital role in reducing the use of chemical additives and preservatives. It also improves consumer's satisfaction by obtaining healthier and ready-to-use foods [27]. There have been several studies on the enrichment of fermented milk products with probiotics, such as enrichment of Cheddar [28], Manchego [29], Cottage [30], Turkish Beyaz [31], Argentinean [32], and white cheese [33].

Among probiotic bacteria, $L$. plantarum, L. casei, and L. helveticus were present in high enough levels $\left(10^{6} \mathrm{CFU} / \mathrm{g}\right.$ threshold) throughout the storage, which is required for probiotic activity and having satisfactory viability (count decreases during 60 days $<3$ log order) in cheese. In the current study, L. agilis, $L$. delbrueckii, and $L$. salivarius reduced at least 4 logs during 60 days of the storage and reached to the final count of $<5.52 \pm 0.07 \log$ CFU/g. The adverse conditions such as low $\mathrm{pH}$, lack of carbohydrates, and probably unfavorable ambient temperature during 60 days of the storage might be responsible for this reduction [34]. This reduction in Lactobacillus population, constructed various strategies such as microencapsulation with different materials to protect microorganisms for the gradual release of microorganism in cheese [35].

\section{Conclusion}

Results of this study indicated that bacterial isolates obtained from traditional cheeses could be used in industrial cheese production to obtain exclusive properties of traditional cheeses. The outcome of the study also showed that L. plantarum, L. casei, and $L$. helveticus are good combinations of starter cultures with acceptable viability.

\section{Authors' Contributions}

AE supervised the project. MH carried out the experiment. AA wrote the manuscript with support from Dr. Ehsani and Hashemi. MA contributed to the final version of the manuscript. All authors read and approved the final manuscript.

\section{Acknowledgments}

This work was supported by the vice chancellor of research, Urmia University, Urmia, Iran under Grant No. 1587.

\section{Competing Interests}

The authors declare that they have no competing interests.

\section{References}

1. Montel, M.C., Buchin, S., Mallet, A., Delbes-Paus, C., Vuitton, D.A., Desmasures, N. and Berthier, F. (2014) Traditional cheeses: Rich and diverse microbiota with associated benefits. Int. J. Food. Microbiol., 177: 136-154.

2. Durlu-Ozkaya, F., Xanthopoulos, V., Tunail, N. and Litopoulou-Tzanetaki, E. (2001) Technologically important properties of lactic acid bacteria isolates from Beyaz cheese made from raw ewes' milk. J. Appl. Microbiol., 91: 861-870.

3. Incheh, K.H.G., Hassanzadazar, H., Forouzan, S.H., Banafshehchin, E.L., Mozafarian, E.L., Aminzare, M. and Hashemi, M. (2017) A survey on the quality of traditional butters produced in West Azerbaijan province, Iran. Int. Food Res. J., 24: 327-332.

4. Aminifar, M. and Emam-Djomeh, Z. (2014) Changes of texture, microstructure and free fatty acid contents of lighvan cheese during accelerated ripening with lipase. J. Agric. Sci. Technol., 16: 113-123.

5. Ehsani, A., Mahmoudi, R., Hashemi, M. and Raeisi, M. (2014) Identification of Lactobacillus species isolated from traditional cheeses of west Azerbaijan. Iran. J. Med. Microbiol., 8: 38-43.

6. Milani, E., Shahidi, F., Mortazavi, S.A. and Saeedi, M. (2017) Isolation and identification of lactic acid bacteria in kurdish cheese during ripening using $16 S$ rRNA gene sequence analysis. J. Food Process Preserv. 41: e13009.

7. Tajik, H., Aminzare, M., Raad, T.M., Hashemi, M., Azar, H.H., Raeisi, M. and Naghili, H. (2015) Effect of Zataria multiflora Boiss essential oil and grape seed extract on the shelf life of raw buffalo patty and fate of inoculated Listeria monocytogenes. J. Food Process Preserv., 39: 3005-3013

8. Mannan, S.J., Rezwan, R., Rahman, M.S. and Begum, K. (2017) Isolation and biochemical characterization of Lactobacillus species from yogurt and cheese samples in Dhaka metropolitan area. Bangladesh Pharm. J. 20: 27-33.

9. Krasaekoopt, W., Bhandari, B. and Deeth, H. (2004) The influence of coating materials on some properties of alginate beads and survivability of microencapsulated probiotic bacteria. Int. Dairy, 14: 737-743.

10. Colombo, E., Franzetti, L., Frusca, M. and Scarpellini, M. (2010) Phenotypic and genotypic characterization of lactic acid bacteria isolated from artisanal Italian goat cheese. $J$. Food Protect., 73: 657-662.

11. Hatamikia, M., Bahmani, M., Azar, H.H., Sepahvand, R., Parsaei, P. and Aminzare, M. (2016) Microbial contamination of commercial and traditional doogh dairy products in Lorestan province of Iran. J. Food Qual. Hazards Control, 3: 114-116.

12. Diezhandino, I., Fernández, D., González, L., McSweeney, P.L.H., and Fresno, J.M. (2015) Microbiological, physico-chemical and proteolytic changes in a Spanish blue cheese during ripening (Valdeón cheese). Food Chem., 168: 134-141.

13. Ahmadi, S.M., Khamiri, M., Khosroshahi,A. and Nezhad, M.K. (2009) Isolation and identification of Lacic acid bacteria from Lighvan cheeses. J. Agric. Sci. Nat. Res., 3: 80-91.

14. Centeno, J., Cepeda, A. and Rodriguez-Otero, J. (1996) Lactic acid bacteria isolated from Arzu' a cows' milk cheese. Int. Dairy J., 6: 65-78.

15. Mannu, L., Comunian, R. and Scintu, M.F. (2000) Mesophilic Lactobacilli in Fiore Sardo cheese: PCRidentification and evolution during cheese ripening. Int. Dairy J., 10: 383-389.

16. De Angelis, M., Corsetti, A., Tosti, N., Rossi, J., Corbo, M. and Gobbetti, M. (2001) Characterization of non-starter lactic acid bacteria from Italian ewe cheeses based on phenotypic, genotypic, and cell wall protein analyses. Appl. Environ. Microbiol., 67: 2011-2020.

17. Beukes, E.M., Bester, B.H. and Mostert, J.F. (2001) The 
microbiology of South African traditional fermented milk. Int. J. Food Microbiol. 63: 189-197.

18. Mathara, J.M., Schillinger, U., Kutima, P.M., Mbugua, S.K. and Holzapfel, W.H. (2004) Isolation, identification and characterisation of the dominant microorganisms of kule naoto: The Maasai traditional fermented milk in Kenya. Int. J. Food Microbiol., 94: 269-278.

19. Abdi, R., Sheikh-Zeinoddin, M. and Soleimanian-Zad, S. (2006) Identification of lactic acid bacteria isolated from traditional Iranian Lighvan cheese. Pak. J. Biol. Sci., 9: 99-103.

20. Terzic-Vidojevic, A., Vukasinovic, M., Veljovic, K., Ostojic, M. and Topisirovic, L. (2007) Characterization of microflora in homemade semi-hard white Zlatar cheese. Int. J. Food Microbiol., 114: 36-42.

21. Randazzo, C.L., Vaughan, E.E. and Caggia, C. (2006) Artisanal and experimental Pecorino Siciliano cheese: Microbial dynamics during manufacture assessed by culturing and PCR-DGGE analyses. Int. J. Food. Microbiol., 109: 1-8.

22. Parvez, S., Malik, K., Ah Kang, S. and Kim, H.Y. (2006) Probiotics and their fermented food products are beneficial for health. J. Appl. Microbiol., 100: 1171-1185.

23. Singh, P. and Prakash, A. (2009) Screening of lactic acid bacteria for antimicrobial properties against Listeria monocytogenes isolated from milk products at Agra region. Int. J. Food Saf., 11: 81-87.

24. Naghili, H., Tajik, H., Raiesi, M., Ghasemmahdi, H., Moradi, M., Zare, M.A., Mehdizade, T., Hasanazar, H. and Hariri, F. (2016) Inhibitory potential of metabolites from Lactobacillus casei against phenotypic characteristic of Salmonella typhimurium LT2. Med. Lab. J., 10: 7-13.

25. Aminzare, M., Abbasi, Z., Amiri, E., Hashemi, M., Raeisi, M., Mousavi, N., Hassanzadazar, H. (2017) Colibacillosis phytotherapy: An overview on the most important world medicinal plants effective on Escherichia coli. J. Pharm. Sci. Res., 9: 629-636.

26. Hashemi, M., Ehsani, A., Hassani, A., Afshari, A., Aminzare, M., Sahranavard, T. and Azimzadeh, Z. (2017) Phytochemical, antibacterial, antifungal and antioxidant properties of Agastache foeniculum essential oil. J. Chem. Health Risks. 7: 95-104.

27. Naghili, H., Tajik, H., Aliakbarlu, J., Zare, P., Ghasemmahdi, H., Raiesi, M. and Amin Zare, M. (2014) Application of Lactobacillus casei and Temperature to control of Salmonella Typhimurium under in vitro conditions. Urmia Med. J., 24: 1005-1015.

28. Ryan, P.M., Burdikova, Z., Beresford, T., Auty, M.A.E., Fitzgerald, G.F., Ross, R.P., Sheehan, J.J. and Stanton, C. (2015) Reduced-fat cheddar and swiss-type cheeses harboring exopolysaccharide-producing probiotic Lactobacillus mucosae DPC 6426. J. Dairy Sci., 98: 8531-8544.

29. Salazar-Montoya, J.A., González-Cuello, R., Flores-Girón, E. and Ramos-Ramírez, E.G. (2018) Effect of free and microencapsulated Lactococcus lactis on composition and rheological properties of Manchego-type cheeses during ripening. Food Res. Int., 105: 59-64.

30. Jeon, E.B., Son, S.H., Jeewanthi, R.K.C., Lee, N.K. and Paik, H.D. (2016) Characterization of Lactobacillus plantarum Lb41, an isolate from kimchi and its application as a probiotic in cottage cheese. Food Sci. Biotechnol., 25: 1129-1133

31. Kasımoğlu, A., Göncüoğlu, M. and Akgün, S. (2004) Probiotic white cheese with Lactobacillus acidophilus. Int. Dairy J., 14: 1067-1073.

32. Bergamini, C., Hynes, E., Quiberoni, A., Suarez, V. and Zalazar, C. (2005) Probiotic bacteria as adjunct starters: Influence of the addition methodology on their survival in a semi-hard Argentinean cheese. Food Res. Int., 38: 597-604.

33. Yerlikaya, O. and Ozer, E. (2014) Production of probiotic fresh white cheese using co-culture with Streptococcus thermophilus. Food Sci. Technol., 34: 471-477.

34. Ong, L. and Shah, N.P. (2009) Probiotic cheddar cheese: Influence of ripening temperatures on survival of probiotic microorganisms, cheese composition and organic acid profiles. LWT Food Sci. Technol., 42: 1260-1268.

35. Kailasapathy, K. and Masondole, L. (2005) Survival of free and microencapsulated Lactobacillus acidophilus and Bifidobacterium lactis and their effect on texture of feta cheese. Aust. J. Dairy Technol., 60: 252. 